\title{
Shine Your Light Wherever You Go
}

\author{
Shanty Sigrah Asher \\ We cannot always build the future for our youth, but we can build our \\ youth for the future.
}

Franklin D. Roosevelt

Like many other Micronesians, my family and I are blessed we live Hawai'i. I dedicate this essay to our Micronesian youth. You are strong, beautiful, smart, and valued; never let anyone tell you otherwise.

I was once in your shoes. Let me tell you my story.

My home, Kosrae, is a forty-two square mile volcanic island in the Federated States of Micronesia (FSM), home to over 6,000 of the world's friendliest people. Then and now, the United States has been a big part of our livelihood and upbringing. We started learning the English language as early as pre-school. Our desire to know about America and her democracy was so strong that we learned more about it than about our own nation. A long-standing and steadfast relationship between FSM and the United States drives these desires, from the times of the Trust Territory of the Pacific Islands (TTPI) to the Compact of Free Association (COFA). Many of us take pride in this relationship, promised and built upon a mutual respect found nowhere else in the world.

In exchange for exclusive American control over FSM's water and air space, we can live and work in the US. This relationship opened up a door for me and countless others from FSM to enter visa-free, and gain access to the US's quality education system. After graduating from Malem Elementary School in 1996 and Kosrae High School in 1999, I enrolled at Chaminade University on O'ahu. The experience was exciting and terrifying. It was my first time living away from my family. Because I was one of a very few students who spoke English with a deep accent, my teachers and classmates found it hard to understand me. With no Facebook messenger, Zoom, or Skype to see family and friends, I was often homesick, and cried myself to sleep. On lucky weeks, I would buy a five-dollar phone card, and use the lobby payphone to talk to my family-for ten minutes. Life was arduous, but at eighteen, I learned to manage the little money I had. 
In my second semester, I became less shy and more confident. I made friends and found my second Pacific Islander family-American and Western Sāmoans, Native Hawaiians, and Micronesians. Our values and struggles were similar. We all came from loving, caring, family-directed and oriented communities, so we took care of each other - sharing what we had, lifting each other up, and surviving financially and spiritually together. As Pacific Islanders, our bond made us stronger together. We knew that our ocean does not divide us, but unites us.

A feeling that seems almost nonexistent today.

After receiving my bachelor's and master's at Chaminade, I returned home to FSM. It was time to serve the country and people who had supported my education. My family of four moved to Pohnpei, the capital of FSM, where I spent five years as a Deputy Assistant Secretary of Pacific Affairs at Foreign Affairs. This chapter changed my life, offering me countless opportunities to serve, work alongside, and learn from admirable world leaders and diplomats and selfless community members.

A deeper and stronger desire to serve, and especially to protect citizens' rights enshrined in the Constitution, led me with my family to law school in August 2015, in "America's finest city," San Diego. Law school was frightening and surreal. As a child I had dreamed about becoming a lawyer, but when it was really happening, I started doubting myself. I was surrounded by incredibly strong, capable, and intelligent law students. The process was intimidating, but through determination, faith, and constant reminders of my family's and people's sacrifices, I told myself there was no room for failure-their sacrifices would not go unnoticed. I pushed through, juggling my responsibilities as a wife, mom, and law student. Thanks to my husband, our families, and our San Diegan friends and families, whom we love dearly and miss, we completed our mission. On May 12, 2018, I graduated with a Juris Doctor, and my little family returned to Hawai' $i$.

Being back in my second home was fulfilling yet heartbreaking — certainly a different story from when I first came. In 1999, not many people knew about "Micronesians." Not being very noticeable gave us peace and comfort. In 2020, however, "Micronesians" are noticed-and not in a good way. I now hear phrases like "Go back to your home country," or "You bunch of cockroaches." At school, amongst the hurtful comments thrown at our kids, my daughter was told, "You Micronesian? Nahhh, you too smart to be Micronesian." Over the past decade, this discrimination has become acceptable and constant in Hawai' $i$. Though efforts are made to tackle this injustice, these are troubling and challenging times for our kids, who are expected to cope and survive, as well as learn and dream about their futures - overwhelming responsibilities at such a young age.

I, like so many community members, did not want to lose hope. I did not want my daughters in Hawai ' $\mathrm{i}$ to grow up with hate-it is "un-Pacific." A Pacific way is to treat everyone as family, with respect and compassion. Hawai' $i$ is a Pacific neighbor. 
Papa Mau Piailug taught Hawaiians the art of non-instrument navigation, uniting navigators and reawakening cultural pride and unity throughout Polynesia.

I am thankful to Pacific Resources for Education and Learning (PREL), my employer, for recruiting me to work with our communities on education and true Pacific values. Since my return, I have done a great deal of community outreach, assisting Micronesians one-on-one with REAL ID issues and unemployment, raising awareness about rights and responsibilities, and visiting schools to talk to students and educators about how we can better support our Micronesian students. If we can feel welcomed, appreciated and valued, cooperation and civic contributions will happen.

In February 2020, I was invited to talk to the principal and faculty at Kealakehe High School in Kailua-Kona about "Supporting Micronesian Students in Hawai' $i$ Schools," part of Culturally Responsive Teaching training conducted by PREL. Because the presentation was in the afternoon, I arrived early to tour the school, and to meet and speak with teachers and our Micronesian students. It was a beautiful and memorable day, as I was embraced with the presence of over forty young, smart, and full-spirited Micronesian students, who forfeited their lunch break to talk story by the tree where they usually hung out. I told them about my journey; what it had been like coming to Hawai'i for school, and the challenges I endured and overcame. I felt they were inspired, because they asked me to return to help them with their financial aid applications, and to speak to them in a more organized setting about vocational training opportunities and career pathways. It was a fruitful day!

The same day, to inform and empower, in a history class I spoke to over twenty seniors, Micronesians and non-Micronesians, about the Compact of Free Association. Directing their attention to a big map, I pointed to the block of water belonging to COFA nations, and spoke briefly of what these three million square miles mean for national security and peace for the United States and Hawai'i. I also highlighted COFA's hope that FSM people will seek better opportunities, and be good ambassadors wherever our pursuits take us.

I strove for two things that day. For the non-Micronesian youth, to develop a deeper understanding, so that they could find in their hearts ways to look at and appreciate their peers and our community differently. For the Micronesian youth, to instill hope, self-worth, and a sense of responsibility. On that day, all the students were silent and attentive. I was certain something was learned.

My dream is that we can soon live in harmony-that our daughters can wear their skirts and dresses in public proudly, and that Micronesians are recognized for the good that we do. I have hopes, because on July 1, 2020, Governor David Ige nominated me, and the Hawai' $i$ Senate confirmed me, to serve as a member of the Hawai'i Board of Education - the first Micronesian in this capacity. It's a historic decision, showing Hawai' i's commitment to become part of the solution. 
To our Micronesian youth—be proud of who you are. You come from rich cultural backgrounds. Treasure your roots and identity. Your uncles, aunties, brothers, and sisters are fighting and sacrificing every day in the name of freedom. In return, be good ambassadors wherever you are. At school, follow rules and help your fellow students. At the public parks, respect the rules and leave the area better than you found it. Empower each other and always be respectful, remember where you come from, and always put God first in all you do.

May we continue to shine our lights wherever we go and whenever we can.

I am Shanty Sigrah Asher. Wife of Ronnie Asher, mother of Shanielyn, Ayorine, and Elmerlyn. Daughter of Deborah and Sankey Sigrah. Oldest of seven siblings: Darlene, Raleigh, Kathleen, Rebecca, Dessah, and Sihna. I am Kosraen, Pohnpeian, and a proud Micronesian. 